Article

\title{
The Effects of Silvicultural Treatment on Sirex noctilio Attacks and Tree Health in Northeastern United States
}

\section{Kevin J. Dodds *, Robert R. Cooke and Ryan P. Hanavan}

U.S. Department of Agriculture Forest Service, Northeastern Area State and Private Forestry, 271 Mast Rd., Durham, NH 03824, USA; E-Mails: rcooke@fs.fed.us (R.R.C.); rhanavan02@fs.fed.us (R.P.H.)

* Author to whom correspondence should be addressed; E-Mail: kdodds@fs.fed.us; Tel.: +1-603-868-7743; Fax: +1-603-868-1066.

External Editor: Eric J. Jokela

Received: 13 October 2014; in revised form: 4 November 2014 / Accepted: 11 November 2014 / Published: 19 November 2014

\begin{abstract}
The invasive woodwasp Sirex noctilio (Hymenoptera: Siricidae) is established in east-central North America. A replicated case study testing the effectiveness of silvicultural treatments for reducing the number of $S$. noctilio attacked trees in a stand was conducted in New York, USA. Silvicultural treatments reduced $S$. noctilio attacked trees by approximately $75 \%$ over the course of the study. There was no tree growth response to silvicultural treatments in the four years after thinning, but targeted removal of weakened trees removed potential $S$. noctilio habitat from treated stands. Two spectral vegetation indices were used to determine tree health in each treatment and potentially provide guidance for detection efforts. Silvicultural treatment significantly influenced the Red Edge Inflection Point, a strong indicator of chlorophyll content, and the Moisture Stress Index, a reflectance measurement sensitive to changes in foliar leaf water content, with the greatest differences occurring between control and treated blocks. Vegetation indices showed promise as a tool for aiding in stand prioritization for $S$. noctilio surveys or management activities.
\end{abstract}

Keywords: tree health; stand thinning; spectral analysis; vegetation indices 


\section{Introduction}

In the decade since its discovery, Sirex noctilio has been detected over a large area of east-central North America including New York, Pennsylvania, Ohio, Michigan, Vermont, Connecticut, and New Jersey in the United States of America, and Canadian provinces including Ontario and Quebec [1]. Primarily Eurasian in origin, $S$. noctilio has been accidentally introduced into seven southern hemisphere countries, including Argentina, Australia, Brazil, Chile, New Zealand, South Africa, and Uruguay [2,3]. These countries have large areas of commercial plantations of North American pine species, often growing under stressed conditions in unthinned stands. Because of its invasive history and other factors, S. noctilio was considered a high-risk pest of concern for North America [4].

Large areas of North America contain commercially planted and natural pine species that are known to support $S$. noctilio development in other countries where they are grown. Confirmed $S$. noctilio hosts include southern (Pinus taeda L., Pinus echinata P. Mill., Pinus elliottii Engelm.), western (Pinus radiata D. Don, Pinus ponderosa P. \& C. Lawson, Pinus contorta Douglas ex Loudon), and Midwestern (Pinus banksiana Lamb.) species [2] that have been planted commercially throughout the Southern Hemisphere. To date, S. noctilio has been found in Pinus resinosa Ait., Pinus sylvestris L., Pinus strobus L., and P. banksiana where it has established in North America [1,5]. North American regions where these and other pines grow, especially where they are intensively planted and managed, are particularly at risk for $S$. noctilio damage.

Similar to its native range, S. noctilio has been found primarily in suppressed trees within overstocked stands in North America. Pinus sylvestris stands appear to suffer higher levels of tree mortality than $P$. resinosa, suggesting $S$. noctilio may be more attracted to its ancestral host [6]. Sirex noctilio attacked trees in these stands were generally smaller in diameter, had slower growth, and reduced crowns compared to larger, faster growing trees with more developed crowns. Very few large diameter $(>30 \mathrm{~cm} \mathrm{dbh})$, dominant trees were attacked in infested stands. Sirex noctilio's preference for attacking suppressed trees makes silvicultural treatment targeting this habitat a promising tool for reducing populations of this insect in North America.

Well-developed integrated pest management plans already exist and offer the best hope for minimizing the impact of $S$. noctilio in North America if it reaches damaging levels [7-10]. Successful integrated pest management plans for $S$. noctilio have several components, including survey and monitoring activities, biological control through a host-specific nematode (Beddingia siricidicola) and parasitic Hymenoptera (Ichneumonidae, Ibaliidae), and appropriate silvicultural treatments to improve individual tree vigor and reduce stand susceptibility [8,11]. These components have helped reduce S. noctilio-caused tree mortality and the economic impact of this insect where implemented.

Biological control provides an important tool for S. noctilio management and has been a key component for keeping populations below damaging levels in several countries. However, silvicultural treatments offer a solution that can reduce susceptibility to this insect as well as other conifer-inhabiting native species. Good silvicultural practices that promote individual tree vigor should translate to any forest regardless of tree species or location. Sirex noctilio targets high stand density, small diameter, unthinned stands where it concentrates attack on stressed and/or suppressed trees [6,10]. Silvicultural treatments, such as thinning from below, that target suppressed trees will remove $S$. noctilio habitat 
while simultaneously increasing residual tree vigor. These types of treatments have been recommended to reduce the impact of $S$. noctilio in commercial forests throughout the Southern Hemisphere $[8,10,12]$.

While silvicultural treatments are commonly recommended to reduce the impact of $S$. noctilio on pine stands $[8,10]$, it is unknown how effective these treatments will be in North America on a new (P. resinosa) and ancestral ( $P$. sylvestris) host tree. Additionally, limited quantitative data of stand thinning effects on $S$. noctilio exist to guide thinning recommendations. A demonstration silvicultural study was conducted in northern New York to address this data gap and assess the feasibility of thinning stagnant stands to reduce $S$. noctilio attacks on trees. Further, remote sensing techniques were used to investigate tree health metrics within treatment areas as a potential tool to assist stand prioritization and land management.

\section{Experimental Section}

\subsection{Site}

Stand thinnings were conducted on Fort Drum Military Base, a 43,408 ha (107,265 ac) installation located near Watertown, NY. Approximately 21,045 ha of hardwood and conifer forests are under active management on the base, with $P$. resinosa, $P$. strobus, and $P$. sylvestris present in pure and mixed stands. Sirex noctilio infested trees were confirmed on Ft. Drum in 2006 (Kevin J. Dodds, personal observation). Two pine stands, one $P$. resinosa dominated and one $P$. sylvestris dominated, were selected from available hard pine stands to assess stand thinning as a $S$. noctilio management tool in North America. Stands were located in Jefferson County, at elevations between 200 and $240 \mathrm{~m}$. Stands were separated by approximately $17 \mathrm{~km}$. Three major soil groups occur in the two stands: Plainfield sand, $0 \%-8 \%$ slope (Map Unit PoB); Plainfield sand, rolling (Map Unit PoC); and Windsor loamy fine sand, $0 \%-8 \%$ slope (Map Unit $\mathrm{WoB}$ ). All three groups are deep and excessively drained, with depth to top of seasonal high water table $>152 \mathrm{~cm}$. Consequently, available water capacity is very low in these stands.

Both stands were selected based on two factors: (1) presence of $S$. noctilio attacks from the previous year distributed throughout the stand; and (2) overstocked stand conditions that provided habitat conducive to insect colonization. Ground surveys were conducted to determine the presence of recently attacked trees, using only resin beads as indication of S. noctilio presence [13]. Presence of resin beads on trees indicated that $S$. noctilio attempted to colonize trees in the stand the previous year. Sirex noctilio tests trees for oviposition suitability [14] and not every tree with resin beads will be associated with successful reproduction. However, even in trees where no eggs are laid, S. noctilio deposits its symbiotic fungus and injects a toxic mucus; these two factors acting alone can successfully kill trees [15]. The two study stands were unmanaged, even-aged pole stands that were experiencing reduced growth and self-thinning from the overstocked conditions.

\subsection{Study Design}

In both stands, 0.4 ha (=1 ac) rectangular blocks were allocated throughout each stand so that three replicates of a control and two thinning treatments (light, heavy) were established. A total of nine 
0.4 ha blocks were placed in each stand and randomly assigned as a control or treatment. Treatment blocks were buffered by $10 \mathrm{~m}$ from any forest edge.

\subsection{Pinus resinosa Stand}

The stand selected to test $S$. noctilio response to thinning in $P$. resinosa was an almost pure 8.5 ha stand, with the exception of a $P$. sylvestris inclusion in one area. This stand was located in an active training area on Ft. Drum that is a mix of hardwood and conifer forests as well as other habitats. Average $( \pm \mathrm{SE})$ tree diameter in the stand was $15.5 \pm 0.3 \mathrm{~cm}$. Average stand basal area was $43.6 \pm 3.5 \mathrm{~m}^{2} / \mathrm{ha}$. Thinning treatments in the $P$. resinosa stand were carried out as timber management improvement cuts, with all felled trees bucked into several sections and left on site.

\subsection{Pinus sylvestris Stand}

The stand selected to test $S$. noctilio response to thinning in $P$. sylvestris was an almost pure 5.1 ha stand, with the exception of several small inclusions of $P$. resinosa. This stand was located on a more active portion of the base known as the "empoundment" and was adjacent to a highway and military airfield. Average tree diameter was $13.7 \pm 0.3 \mathrm{~cm}$. Stand basal area was $30.5 \pm 1.6 \mathrm{~m}^{2} / \mathrm{ha}$. Unlike the $P$. resinosa stand treatments, all felled trees were removed from the $P$. sylvestris treatments. Slash was chipped, and then removed from the site two months before $S$. noctilio flight commenced in July.

\subsection{Thinning Treatments}

Stands were surveyed for S. noctilio presence during the winter 2007 and all S. noctilio infested trees were marked for removal. Blocks were randomly allocated for control, light, or heavy thinning in each stand. Thinning treatments were considered stand improvement cuts with a combination of sanitation/non-commercial thinning to retain the current even-aged structure in stands. Sanitation included the removal of all $S$. noctilio infested trees and other diseased or damaged trees in each stand. The non-commercial thinning was a dispersed retention, low thinning aimed at increasing sunlight, water, and available nutrients to increase the vigor of residual trees. The control blocks received only sanitation cutting to remove $S$. noctilio infested trees. These infested trees were removed from the $P$. sylvestris control blocks, but remained on site in the $P$. resinosa control blocks.

The post-harvest target of the heavy thin was the B-line defined in the P. resinosa stocking guide as $14 \mathrm{~m}^{2} /$ ha or 988 trees/ha (60 $\mathrm{ft}^{2} \mathrm{ba} / \mathrm{ac}$ or 400 trees/ac) [16]. In comparison, the target of the light thin was $1 / 3$ above the B-line (sometimes recommended for first thinnings outside of the sapling stage), defined as $18 \mathrm{~m}^{2} /$ ha, 1235 trees/ha $\left(80 \mathrm{ft}^{2} \mathrm{ba} / \mathrm{ac}\right.$ or 500 trees/ac). Treatments targeted all suppressed and low vigor trees, trees of poor form, all standing dead, and all $S$. noctilio infested trees. Residual trees were selected for good form, even spacing, and average or better live crown ratio (LCR) relative to other trees in the stand. All thinning treatments and sanitation cutting in control blocks occurred during March and April, 2007, with no tree felling after April 15.

Variable radius plots were established in each treatment block on a diagonal transect after harvesting was complete. Ten factor prisms were used, with species and diameter at breast height $(\mathrm{DBH})$ collected at each point. The target basal areas and trees per hectare for each thinning were 
missed, resulting in slightly higher residual basal areas (Table 1). No stand reentries were possible for basal area adjustments after initial treatments were complete because of an April 15 harvesting moratorium for Indiana bat (Myotis sodalis) conservation efforts. Stand parameters were calculated using NED software [17].

Table 1. Quadratic mean diameter (QMD), trees per hectare, basal area, and target basal area for control and treatment blocks in P. resinosa and P. sylvestris stands.

\begin{tabular}{ccccc}
\hline Treatment & QMD $(\mathbf{c m})$ & Trees per ha & Basal Area $\left(\mathbf{m}^{\mathbf{2}}\right)$ & Target BA $\left(\mathbf{m}^{\mathbf{2}}\right)$ \\
\hline Pinus resinosa & & & & \\
Control & $12.2 \pm 0.5$ & $3547 \pm 523$ & $41 \pm 3$ & NA \\
Heavy Thin & $18.3 \pm 0.8$ & $694 \pm 86$ & $18 \pm 1$ & 14 \\
Light Thin & $16.5 \pm 0.5$ & $1102 \pm 252$ & $23 \pm 2$ & 18 \\
\hline Pinus sylvestris & & & \\
Control & $13.5 \pm 0.5$ & $1835 \pm 178$ & $26 \pm 1$ & NA \\
Heavy Thin & $16.8 \pm 0.5$ & $843 \pm 87$ & $18 \pm 1$ & 14 \\
Light Thin & $15.0 \pm 0.8$ & $1153 \pm 184$ & $21 \pm 1$ & 18 \\
\hline
\end{tabular}

\subsection{Annual Post-Thinning Assessments}

Every pine in each control and treatment block was surveyed annually (2008-2011) to determine the number of $S$. noctilio attacked trees in each block. Sirex noctilio adults are active from July until at least late September [18], so surveys were conducted either in the late spring (2008-2011) before S. noctilio flight or late fall (2011) after flight was complete. Spring surveys recorded tree mortality that had occurred the previous year (2007-2010), while the one fall survey recorded the current year (2011) mortality. Each tree was examined for the presence of resin beads and discolored or dead crowns [13]. Trees that were found attacked in each block were tallied and tree characteristics were noted. It was assumed that all $S$. noctilio attacked trees were physiologically dead. Unexpected base expansion at Fort Drum resulted in the loss of four blocks (1 control, 2 light, 1 heavy) in the P. sylvestris stand during the first year of the study (2007), followed by complete loss during the third year (2009). Consequently, only two years of data are presented from the P. sylvestris stand and no statistical analyses were carried out because of the compromised experimental design.

\subsection{Comparisons of Attacked Trees among Treatments}

Both the average number of attacked trees and the proportion of total trees attacked were compared among the treatments. These two variables were tested because they provide complimentary information regarding $S$. noctilio attacks in pine stands. Number of trees attacked provides estimates of the actual losses within a stand from $S$. noctilio activity, while the proportion of trees attacked provides a relative estimate that accounts for the total number of trees available assuming all are equally susceptible to attack. The number of attacked trees per year was pooled over the 5-year period for each test. Number of trees attacked by treatment was compared with ANOVA with treatment as a fixed effect. The number of attacked trees was $\log _{10}$ transformed to meet the assumptions of ANOVA. Proportion of trees attacked was analyzed using ANOVA with treatment as a fixed effect. Proportion of trees attacked were arcsin square root transformed prior to analysis to meet assumptions of 
ANOVA. Tukey's HSD $(\alpha=0.05)$ was used to make pairwise comparisons among the mean $S$. noctilio attacks occurring in treatment and control blocks.

\subsection{Tree Core Analysis}

Increment cores were removed from 20 randomly selected $P$. resinosa from each block in November 2010 to investigate tree growth patterns in each treatment. Two cores were taken at breast height from each tree, going straight through the pith and through to the other side of trees. Cores were air-dried, sanded, aged, and all annual rings were measured to the nearest $0.01 \mathrm{~mm}$ using a Velmex tree ring system (Velmex, East Bloomfield, New York). Only one core per tree was used for tree growth analyses. Total tree age included only the number of rings measured and no attempt was made to estimate missing annual rings if the pith was missed. Increment cores were visually cross-dated and then run through COFECHA [19] to check for measurement or dating errors. Raw ring width data for each tree were detrended by fitting negative exponential curves or horizontal lines using the dendrochronology program library in R (dplR) [20]. Dimensionless ring width index (RWI) values were created by dividing the observed raw values by expected values from the fitted curves. For each treatment and control block, a growth ratio was created by dividing the average of the RWI's from the 4 years post thinning by RWIs from the 4 years before thinning occurred. Trees were blocked by treatment and average growth ratio was analyzed using PROC GENMOD with treatment as a fixed effect. Growth ratios were transformed using $\log _{10}$ before analysis. Data were then modeled using the normal distribution with identity link.

\subsection{Spectral Reflectance and Remote Sensing}

Ten trees in each block were randomly selected for foliar sampling. Foliar reflectance was measured using a PSR-1100 (350-1100 nm) field portable spectroradiometer (Spectral Evolution, Lawrence, MA, USA) and LF $1250(700-1750 \mathrm{~nm})$ fiber optic lab spectroradiometer (Spectral Evolution, Lawrence, MA, USA). Both PSR-1100 and LF 1250 have a $1.5 \mathrm{~nm}$ nominal bandwidth resulting in approximately 500 data points across the spectral range per sample. Each spectral measurement was preceded by a $99 \%$ reflectance standard measurement taken from a $13 \times 13 \mathrm{~cm}$ white reflectance plate (Spectral Evolution, Lawrence, MA, USA). All foliage was collected from sunlit branches in the upper canopy of each tree on 11 September 2012. A $10 \mathrm{~m}$ buffer was used to avoid selection of any boundary trees. Each foliar sample was stored in a plastic collection bag and kept cool until they were brought back to the lab for analysis. All foliar samples were processed within 24 hours of collection. Leaf illumination was achieved with a $50 \mathrm{~W}$ Tungsten Halogen Spotlight Illuminator (Spectral Evolution, Lawrence, MA, USA). Foliage from each sample was stacked in a flat black petri dish to an approximate depth of $5 \mathrm{~cm}$. Each foliar scan was an average of ten measurements collected through on-board scan averaging for each of the ten trees per replicate. Spectral vegetation indices (VI's) focus on differences in foliar reflectance between the red and near-infared (NIR) regions of the electromagnetic spectrum. Two VI's were tested across silvicultural treatments to determine whether stand susceptibility could be predicted with remote sensing techniques. The Red Edge region has been identified as a sensitive indicator of chlorophyll and nitrogen status [21]. The Red Edge Inflection Point (REIP) is a strong indicator of foliar chlorophyll content where higher values are indicative of 
healthier foliage. Red edge reflectance occurs between $670 \mathrm{~nm}$ and $780 \mathrm{~nm}$ and the REIP is the maximum slope of prominent increase in reflectance between the red and NIR range for green vegetation. Structural and chemical changes of leaves may result in a shift of the REIP and could potentially be used to remotely detect plant stress. The Moisture Stress Index (MSI) was the second VI tested. The MSI is commonly used as an indicator of foliar wetness or dryness. The MSI is commonly used with Landsat satellite imagery where a ratio between Thematic Mapper band 5 (TM5), 1550-1750 nm, and Thematic Mapper band 4 (TM4), 760-900 nm, serves as an approximate measure of leaf turgidity [22]. Higher MSI values are indicative of increased water stress. The formulas for REIP and MSI are as follows:

$$
\begin{gathered}
R E I P=700+40 \frac{[((R 670+R 780) / 2)-R 700]}{R 740-R 700} \\
M S I=\frac{T M 5}{T M 4}
\end{gathered}
$$

Trees were grouped by treatment (2 thinning levels and control) and VI's were analyzed using PROC GLM with DBH and LCR as random effects and treatment as a fixed effect. Tukey's HSD $(\alpha=0.05)$ was used to make pairwise comparisons among VI means in treatment and control blocks.

\section{Results}

\subsection{Stand Thinning to Reduce Sirex noctilio Infestation}

Over the five years of post-thinning surveys, significantly more trees were attacked by $S$. noctilio in P. resinosa control blocks compared to either thinning treatment $\left(F_{2,8}=14.6, P=0.005\right.$; Figure $\left.1 \mathrm{~A}\right)$. There was no difference in $S$. noctilio attacks in either thinning treatment. Annual infestation rates varied, but generally more trees were attacked in control blocks than either treatment (Figure 2). Conversely, the proportion of trees attacked in control and treatment blocks was not significantly different $\left(F_{2,8}=4.7, P=0.06\right.$; Figure $\left.1 \mathrm{~B}\right)$. Because of treatment block losses from construction activities in the $P$. sylvestris stand, the average number of attacked trees in treatments was not statistically compared. However, for the two years that $P$. sylvestris blocks were surveyed more attacked trees occurred in control than treatment blocks (Figure 3). The growth index of trees in the heavy $\left(X^{2}=0.56, d f=1, P=0.45\right)$ and light $\left(X^{2}=0.64, d f=1, P=0.42\right)$ thinning were not significantly different than trees in control blocks (Figure 4 ).

\subsection{Spectral Reflectance and Vegetation Indices}

Red Edge Inflection Point (REIP) values in the control and treatments were significantly different from one another $(F=5.94 ; d f=2,16 ; P=0.02)$. The heavy thinning treatment had the highest mean REIP value $(726.4 \pm 0.111)$ followed by the light thinning $(725.5 \pm 1.11)$ and the control $(722.8 \pm 1.15)$. All three treatments were significantly different from one another with the highest values occurring in the heavy and light thinning treatments, respectively. Moisture stress index (MSI) values were also significantly different $(F=2.99 ; d f=2,16 ; P=0.05)$ where the control had the highest mean MSI value $(0.744 \pm 0.054)$ followed by light thinning $(0.704 \pm 0.036)$ and heavy thinning $(0.549 \pm 0.032)$. The heavy thin was significantly different from both light thin and control and there 
were no statistical differences between the light thinning and control treatments. These results suggest the heavy thinning treatment had the highest overall leaf water content.

Figure 1. (A) Average ( $\pm \mathrm{SE})$ number and (B) proportion of Pinus resinosa attacked by Sirex noctilio in control and thinning treatments $(N=3)$.
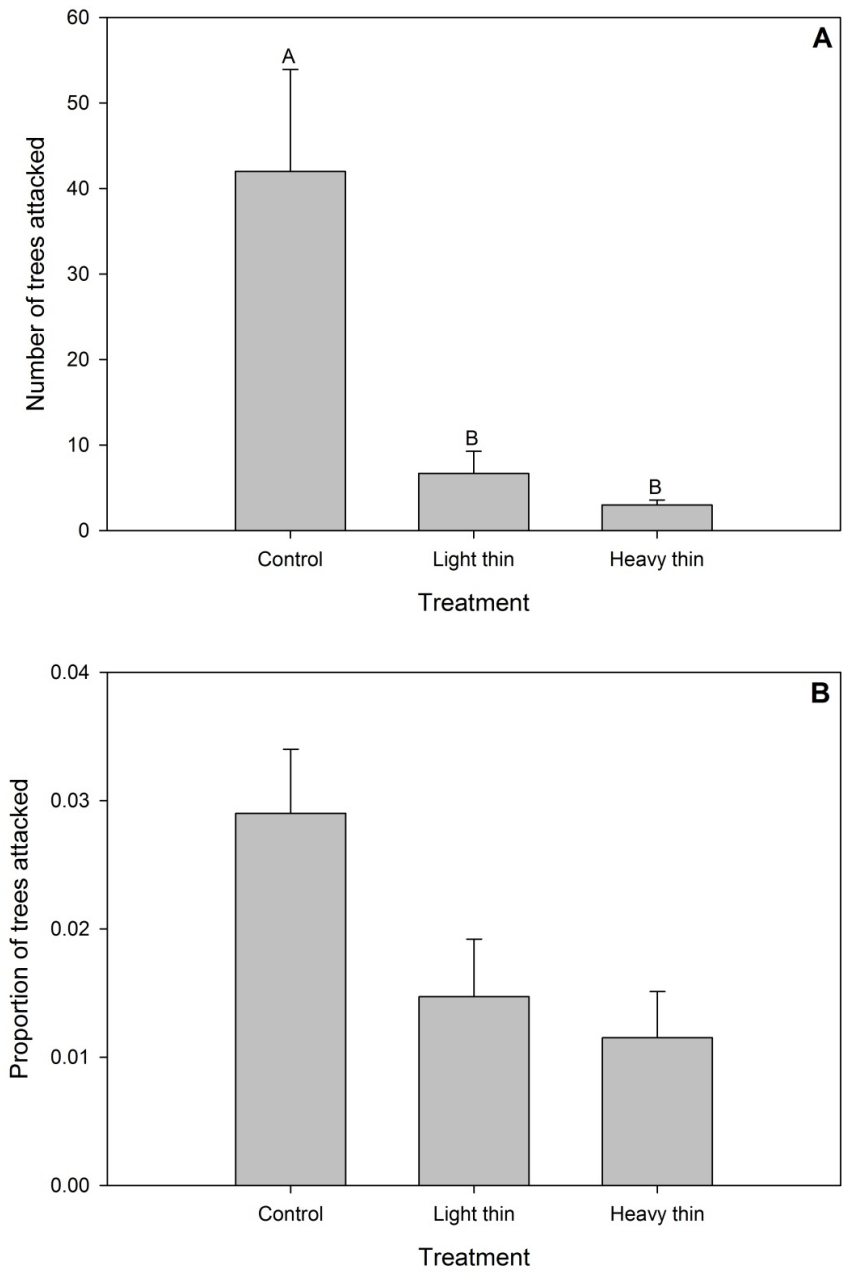

Figure 2. Average $( \pm \mathrm{SE})$ annual number of Pinus resinosa attacked by Sirex noctilio in control and thinning treatments $(N=3)$ over the survey period.

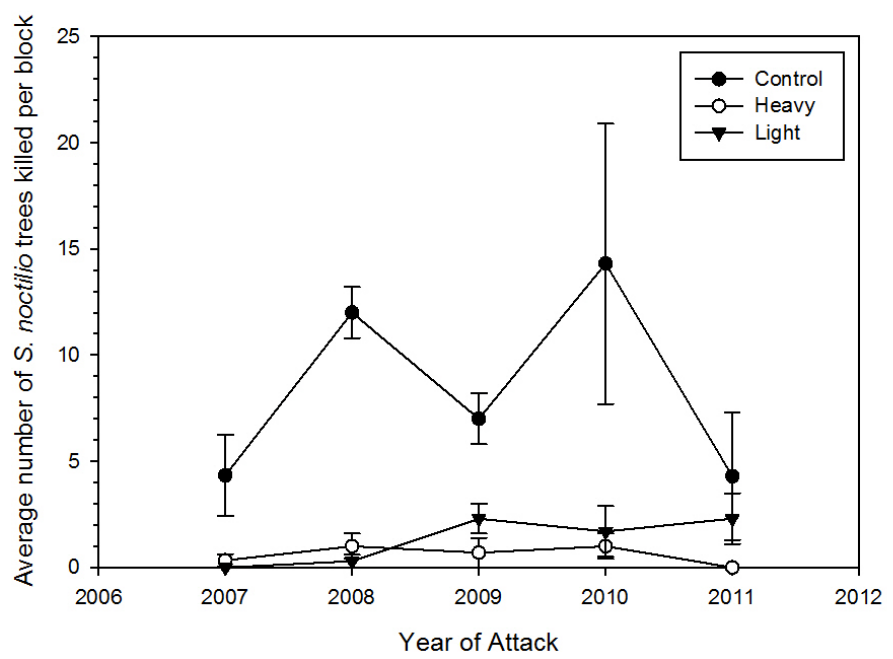


Figure 3. The number of Pinus sylvestris attacked by Sirex noctilio in control and thinning treatments; note that no statistics were conducted on these data because of loss of replicates.

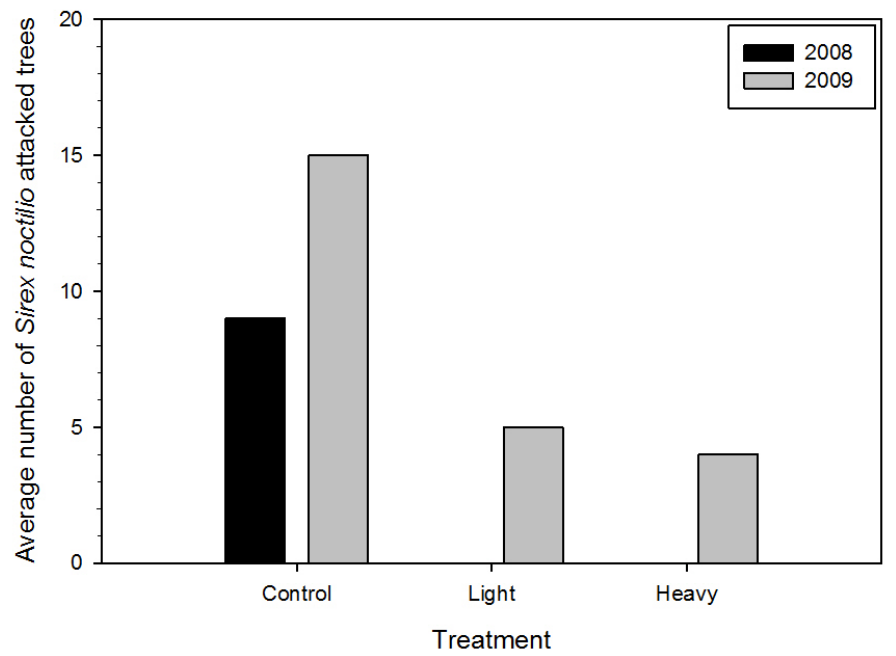

Figure 4. Average $( \pm \mathrm{SE})$ Pinus resinosa ring width index ratio for trees in control and thinning treatments.

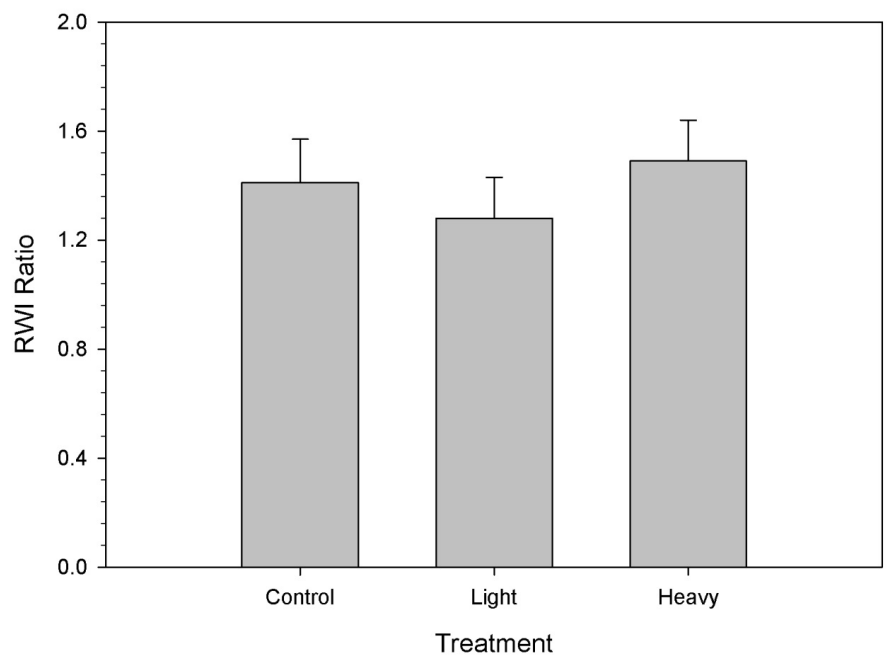

\section{Discussion}

Silvicultural treatments have successfully reduced the negative effects of some insects on conifer forests in North America [23] and it appears stand thinning treatments targeting suppressed material may reduce susceptibility to $S$. noctilio as well. In $P$. resinosa and $P$. sylvestris stands in New York, both stand thinning treatments reduced the number of $S$. noctilio attacked trees, suggesting that silviculture could be used to reduce tree attacks in high risk, high hazard pine stands in the northeastern United States. On average there were over $80 \%$ more $P$. resinosa attacked in control stands compared to either thinning treatment. Pinus sylvestris followed a similar pattern with no attacks in treatments the first year and at least 75\% more attacks in controls compared to either thinning treatment the second year.

Although not statistically significant, the proportion of total trees attacked by $S$. noctilio in $P$. resinosa was twice as high in controls compared to the two thinning treatments. Previous thinning 
studies have used total trees or basal area killed [24-26], proportion of trees [27,28], or both [29,30] when assessing effectiveness of silvicultural treatments. While we tested proportion of total trees attacked and the total number of trees attacked, the former may not be an appropriate measure for assessing $S$. noctilio response to stand thinnings. Sirex noctilio is generally found in stressed or suppressed trees [6] and this cohort represents only a portion of the total trees in a stand. We were unable to adequately define this cohort of trees from the data we collected and thus tested the proportion of total trees in a stand. Since a component of our thinning treatments was the removal of potential $S$. noctilio habitat through thinning from below, comparing the number of attacked trees is a better estimate of treatment effectiveness than proportion of total trees. Proportional comparisons do not account for the targeted removal of habitat through thinning and treat all trees in each stand as equally available $S$. noctilio habitat, something that has been documented to be untrue. Consequently, the total trees attacked in each block represents a more realistic test of thinning as silvicultural treatments targeted $S$. noctilio habitat with the goal of reducing the number of stems and basal area in treated stands.

Thinnings may have been more effective than assessed had they been as intense as planned in treatment blocks. The residual basal area in most blocks was higher than original targets, with some trees that were marked for removal missed during the thinning operation. Even with residual basal areas higher than planned, $S$. noctilio attacks were much fewer in treated blocks compared to controls. In several instances marked trees were found to be attacked by $S$. noctilio during annual surveys. Had thinning targets been met and all target trees removed, further reductions in tree attacks in the thinned blocks would have been documented.

There were no detectable growth differences among trees from the control and two thinning treatments in P. resinosa. By thinning stands, more resources are made available to residual trees that can be used for growth or improved host defenses. Stand conditions have been related to host defenses and can influence insect colonization [31-33]. While host defenses were not measured during this study, there were no differences in the post-thinning growth rates in trees. Trees throughout both the $P$. resinosa and $P$. sylvestris stands generally had poor crown development and small live crown ratios $(<30 \%)$, and were growing in stands with relatively low site indices (55, base age 50$)$ coupled with soils that were excessively drained sands. Trees such as these often have difficulty responding to thinning treatments [34,35] and may explain why no growth response was seen. Silvicultural treatments occurring earlier in stand development in both these stands likely would have resulted in increased post-thinning growth. Even with no measureable growth differences among control and treatment blocks, $S$. noctilio attacks were lower in treated blocks. It is also possible that trees responded to the thinnings in ways not related to direct tree growth (e.g., host defenses).

Improving vigor in individual trees was one way that treatments could influence $S$. noctilio behavior in stands and this may occur over longer time frames than the current study. A more direct thinning impact on S. noctilio was the removal of preferred habitat (i.e., suppressed, damaged, or dying trees). There is a strong relationship between $S$. noctilio and suppressed trees $[6,10]$ and this material is easy to target and remove with a thinning from below. With no detectable growth response in trees and a reduction in attacks in treated blocks, the likely mechanism for S. noctilio population changes was probably related to habitat loss for the insect. Whatever the mechanism, it appears that stand thinning offers a strong tool to reduce $S$. noctilio attacks in pine stands in North America. 
Understanding host tree defenses and the chemical response of trees under stress can lead to important insights into management options or detection methods for pest species. Biotic and abiotic factors influence tree health, and knowledge of the physiological response of trees to stressors allows for management activities that target weakened trees to be conducted in an effort to minimize disturbances. Sirex noctilio, and its preference for stressed pine trees provided an excellent opportunity to integrate handheld near infrared spectroradiometers with applied studies on individual tree susceptibility and host selection by dispersing insects. As a tree incurs stress (drought, competition, extreme maximum and minimum temperatures, nutrient deficits, insect and disease attack) photosynthesis is reduced and photoprotection mechanisms are relied upon for the safe dissipation of excess energy [36]. Competition appeared to be greatest in the control blocks due to higher densities of smaller diameter trees resulting in increased stress and the two VI's tested support the observation that stress was in fact higher in these blocks. Mean REIP and MSI values suggested higher levels of chlorophyll and lower moisture stress, respectively, were present in trees from the treated blocks compared to untreated controls. Results suggest that both these measures can be used to directly assess chronic reductions in photosynthetic material during periods of stress, similar to other studies [37,38]. These measurements may be useful for determining areas that are susceptible to invasion by $S$. noctilio or other organisms.

North American S. noctilio detection efforts use semiochemical-baited traps, but these have provided mixed results to date. Some previous surveys were guided by remote sensing data and risk models that helped prioritize landscapes for trapping, but methods to assess tree- or stand-level stress would be beneficial for further prioritization of survey areas. Our results suggest that prioritizing stand susceptibility using both broadband (spaceborn multi-spectral data) and narrow band (airborne and handheld hyperspectral data) vegetation indices can help improve survey and detection efforts of S. nocitilo. Ranking conifer stands across a large landscape matrix by size, stand density, and overall health (vegetation indices) may allow land managers to prioritize surveys, biological control, silviculture, and sanitation efforts. Spectral data corresponding to photosynthetic pigments associated with plant stress can be of great value in prioritizing broad-scale survey and management efforts for invasive species and becomes another tool in the integrated pest management toolbox.

\section{Conclusions}

Developing tools that can be helpful for managing the impact of $S$. noctilio in pine-dominated landscapes is important to help mitigate any economic impact associated with this invasive insect. Integrated pest management plans have successfully managed this insect, but testing of these components in North America is important to confidently transfer these techniques to landowners. It is clear from the current study, that silvicultural treatments show promise for managing $S$. noctilio in North America. Silvicultural thinning targeting suppressed trees in a stand successfully reduced the impact of S. noctilio in high-hazard stands. Further, silvicultural treatments such as these will most likely reduce overall stand hazard for other pine-infesting organisms as well.

A set of tools that could help prioritize large landscapes for survey efforts would be beneficial for improving S. noctilio detection efforts. Risk models and coarse stand maps were used to help prioritize surveys after initial $S$. noctilio detection. However, moderate resolution multi-spectral satellite imagery 
such as Landsat 8, along with additional ancillary data, could be used to map stand susceptibility across a landscape using VI's to target high-risk stands for silvicultural intervention and/or targeted biological control. In addition, high-resolution airborne imagery (multi-spectral and hyperspectral) could be used to target high value areas and help pinpoint $S$. noctilio habitat across a diverse landscape matrix.

\section{Acknowledgments}

The authors thank the Forestry group at Ft. Drum Military Base, including Jason Wagner, Rodger Voss, and Travis Ganter whose partnership was critical to the success of the stand thinning project. We also thank U.S. Forest Service personnel including Garret Dubois, Molly Heuss, Jonathan Janelle, Tom Luther, Bob Rabaglia, Richard Reardon, Noel Schneeberger, Nate Siegert, Michael Simmons, and Maria Vasta. Funding for this work was provided by the U.S. Forest Service, Northeastern Area State and Private Forestry and the U.S. Forest Service Forest Health Technology Enterprise Team.

\section{Author Contributions}

All authors contributed to study design, field work, analyses, and writing.

\section{Conflicts of Interest}

The authors declare no conflict of interest.

\section{References}

1. Dodds, K.J.; de Groot, P. Sirex, surveys, and management: Challenges of having Sirex noctilio in North America. In The Sirex Woodwasp and Its Fungal Symbiont: Research and Management of a Worldwide Invasive Pest; Slippers, B., Wingfield, M.J., de Groot, P., Eds.; Springer: New York, NY, USA, 2012; pp. 265-286.

2. Haugen, D.A.; Hoebeke, E.R. Sirex Woodwasp—Sirex noctilio F. (Hymenoptera: Siricidae); NA-PR-07-05; United States Department of Agriculture Forest Service: Newtown Square, PA, USA, 2005.

3. Hurley, B.P.; Slippers, B.; Wingfield, M.J. A comparison of control results for the alien invasive woodwasp, Sirex noctilio, in the southern hemisphere. Agric. For. Entomol. 2007, 9, 159-171.

4. Borchert, D.; Fowler, G.; Jackson, L. Organism Pest Risk Analysis: Risk to the Conterminous United States Associated with the Woodwasp, Sirex noctilio Fabricius, and the Symbiotic Fungus, Amylostereum areolatum (Fries: Fries) Bodin; United States Department of Agriculture: Raleigh, NC, USA, 2007; p. 40.

5. Böröczky, K.; Zylstra, K.; McCartney, N.; Mastro, V.; Tumlinson, J. Volatile profile differences and the associated Sirex noctilio activity in two host tree species in the northeastern United States. J. Chem. Ecol. 2012, 38, 213-221.

6. Dodds, K.J.; de Groot, P.; Orwig, D.A. The impact of Sirex noctilio in Pinus resinosa and Pinus sylvestris stands in New York and Ontario. Can. J. For. Res. 2010, 40, 212-223. 
7. Neumann, F.G. Insect pest management in Australian radiata pine plantations. Aust. For. 1979, 42, $30-38$.

8. Haugen, D.A.; Bedding, R.A.; Underdown, M.G.; Neumann, F.G. National Strategy for Control of Sirex noctilio in Australia; Australian Forest Grower, Special Liftout Section No. 13; Australian Forest Growers: Canberra, Australia, 1990; p. 8.

9. Dodds, K.J.; Cooke, R.R.; Gilmore, D.W. Silvicultural options to reduce pine susceptibility to attack by a newly detected invasive species, Sirex noctilio. North J. Appl. For. 2007, 24, 165-167.

10. Neumann, F.G.; Morey, J.L.; McKimm, R.J. The Sirex Wasp in Victoria; Department of Conservation, Forests and Lands: Victoria, Australia, 1987; p. 41.

11. Haugen, D.A. Control procedures for Sirex noctilio in the Green Triangle: Review from detection to severe outbreak (1977-1987). Aust. For. 1990, 53, 24-32.

12. Eldridge, R.H.; Taylor, E.E. Sirex Woodwasp-A Pest of Pine in N.S.W; Forest Protection Series No. 1; Forestry Commission of New South Wales: Beecroft, NSW, Australia, 1989.

13. Ryan, K.; de Groot, P.; Smith, S.M.; Turgeon, J.J. Seasonal occurrence and spatial distribution of resinosis, a symptom of Sirex noctilio (Hymenoptera: Siricidae) injury, on boles of Pinus sylvestris (Pinaceae). Can. Entomol. 2013, 145, 117-122.

14. Madden, J.L. Oviposition behaviour of the woodwasp, Sirex noctilio F. Aust. J. Zool. 1974, 22, 341-351.

15. Coutts, M.P. Mechanism of pathogenicity of Sirex noctilio on Pinus radiata. II. Effects of S. noctilio mucus. Aust. J. Biol. Sci. 1969, 22, 1153-1161.

16. Benzie, J.W. Red Pine in the North-Central States; United States Department of Agriculture Forest Service General Technical Report; North Central Research Station: St. Paul, MN, USA, 1977; p. 22.

17. Twery, M.J.; Knopp, P.D.; Thomasma, S.A.; Nute, D.E. NED-2 User's Guide; General Technical Report NRS-85; United States Department of Agriculture Forest Service, Northern Research Station: Newtown Square, PA, USA, 2011; p. 193.

18. Zylstra, K.E.; Dodds, K.J.; Francese, J.A.; Mastro, V.C. Sirex noctilio (Hymenoptera: Siricidae) in North America: The effect of stem-injection timing on the attractiveness and suitability of trap trees. Agric. For. Entomol. 2010, 12, 243-250.

19. Holmes, R.L. Computer-assisted quality control in tree-ring dating and measurement. Tree-Ring Bull. 1983, 43, 69-78.

20. Bunn, A.G. A dendrochronology program library in R (dplR). Dendrochronologia 2008, 26, 115-124.

21. Fillella, I.; Peñuelas, J. The red edge position and shape as indicators of plant chlorophyll content, biomass and hydric status. Int. J. Remote Sens. 1994, 15, 1459-1479.

22. Hunt, E.R.; Rock, B.N. Detection of Changes in Leaf Water Content Using Near- and Middle-Infrared Reflectances. Remote Sens. Environ. 1989, 77, 22-33.

23. Fettig, C.J.; Klepzig, K.D.; Billings, R.F.; Munson, A.S.; Nebeker, T.E.; Negron, J.F.; Nowak, J.T. The effectiveness of vegetation management practices for prevention and control of bark beetle infestations in coniferous forests of the western and southern United States. For. Ecol. Manag. 2007, 238, 24-53. 
24. Zausen, G.L.; Kolb, T.E.; Bailey, J.D.; Wagner, M.R. Long-term impacts of stand management on ponderosa pine physiology and bark beetle abundance in northern Arizona: A replicated landscape study. For. Ecol. Manag. 2005, 218, 291-305.

25. Sartwell, C.; Dolph, R.E., Jr. Silvicultural and Direct Control of Mountain Pine Beetle in Second-Growth Ponderosa Pine; United States Department of Agriculture Forest Service, Pacific Northwest Forest and Range Experiment Station: Portland, OR, USA, 1976; p. 8.

26. McCambridge, W.F.; Stevens, R.E. Effectiveness of Thinning Ponderosa Pine Stands in Reducing Mountain Pine Beetle-Caused Tree Losses in the Black Hills-Preliminary Observations; Research Note, RM-414; United States Department of Agriculture Forest Service, Rocky Mountain Forest and Range Experiment Station: Fort Collins, CO, USA, 1982; p. 3.

27. Stark, D.T.; Wood, D.L.; Storer, A.J.; Stephens, S.L. Prescribed fire and mechanical thinning effects on bark beetle caused tree mortality in a mid-elevation Sierran mixed-conifer forest. For. Ecol. Manag. 2013, 306, 61-67.

28. Mitchell, R.G.; Waring, R.H.; Pitman, G.B. Thinning lodgepole pine increases tree vigor and resistance to mountain pine beetle. For. Sci. 1983, 29, 204-211.

29. Fettig, C.J.; Hayes, C.J.; Jones, K.J.; Mckelvey, S.R.; Mori, S.L.; Smith, S.L. Thinning Jeffrey pine stands to reduce susceptibility to bark beetle infestations in California, USA. Agric. For. Entomol. 2012, 14, 111-117.

30. Egan, J.M.; Jacobi, W.R.; Negron, J.F.; Smith, S.L.; Cluck, D.R. Forest thinning and subsequent bark beetle-caused mortality in Northeastern California. For. Ecol. Manag. 2010, 260, 1832-1842.

31. Christiansen, E.; Waring, R.H.; Berryman, A.A. Resistance of conifers to bark beetle attack-Searching for general relationships. For. Ecol. Manag. 1987, 22, 89-106.

32. Waring, R.H.; Pitman, G.B. Modifying lodgepole pine stands to change susceptibility to mountain pine beetle attack. Ecology 1985, 66, 889-897.

33. Lorio, P.L., Jr. Environmental stress and whole-tree physiology. In Beetle-Pathogen Interactions in Conifer Foresets; Schowalter, T.D., Filip, G.M., Eds.; Academic Press: London, UK, 1993; pp. 81-101.

34. Gilmore, D.W.; Palik, B.J. A Revised Managers Handbook for Red Pine in the North Central Region; General Technical Report NC-264; United States Department of Agriculture Forest Service, North Central Research Station: St. Paul, MN, USA, 2006; p. 55.

35. D’Amato, A.W.; Troumbly, S.J.; Saunders, M.R.; Puettmann, K.J.; Albers, M.A. Growth and survival of Picea glauca following thinning of plantations affected by eastern spruce budworm. North J. Appl. For. 2011, 28, 72-78.

36. Peñuelas, J.; Munné-Bosch, S. Isoprenoids: An evolutionary pool for photoprotection. Trends Plant Sci. 2005, 10, 166-169.

37. Peñuelas, J.; Baret, F.; Fillella, I. Semi-empirical indices to assess carotenoids/chlorophyll a ratio from leaf spectral reflectance. Photosynthetica 1995, 31, 221-230. 
38. Merzlyak, M.N.; Gitelson, A.A.; Chivkunova, O.B.; Rakitin, V.Y. Non-destructive optical detection of pigment changes during leaf senescence and fruit ripening. Physiol. Plant. 1999, 106, $135-141$.

(C) 2014 by the authors; licensee MDPI, Basel, Switzerland. This article is an open access article distributed under the terms and conditions of the Creative Commons Attribution license (http://creativecommons.org/licenses/by/4.0/). 